\title{
Review \\ Regulation of BRCA1 expression and its relationship to sporadic breast cancer
}

\author{
Christopher R Mueller ${ }^{1}$ and Calvin D Roskelley ${ }^{2}$
}

\author{
${ }^{1}$ Cancer Research Laboratories, Queen's University, Kingston, Ontario, Canada \\ ${ }^{2}$ Department of Anatomy, University of British Columbia, Vancouver, British Columbia, Canada \\ Corresponding author: Christopher R Mueller (e-mail: muellerc@post.queensu.ca)
}

Received: 14 August 2002 Revisions received: 17 October 2002 Accepted: 25 October 2002 Published: 13 November 2002

Breast Cancer Res 2003, 5:45-52 (DOI 10.1186/bcr557)

(c) 2003 BioMed Central Ltd (Print ISSN 1465-5411; Online ISSN 1465-542X)

\begin{abstract}
Germ-line mutations in the BRCA1 tumour suppressor gene contribute to familial breast tumour formation, but there is no evidence for direct mutation of the BRCA1 gene in the sporadic form of the disease. In contrast, decreased expression of the BRCA1 gene has been shown to be common in sporadic tumours, and the magnitude of the decrease correlates with disease progression. BRCA1 expression is also tightly regulated during normal breast development. Determining how these developmental regulators of BRCA1 expression are co-opted during breast tumourigenesis could lead to a better understanding of sporadic breast cancer aetiology and the generation of novel therapeutic strategies aimed at preventing sporadic breast tumour progression.
\end{abstract}

Keywords: BRCA1, breast cancer, development, transcription, sporadic

\section{Introduction}

The cloning of the BRCA1 gene, and later the BRCA2 gene, were major breakthroughs in our understanding of breast cancer [1]. Both were isolated through traditional positional cloning approaches [2,3] and are probably responsible for the majority of familial breast cancer cases. Our understanding of the multifunctional protein products of the BRCA1 gene and why defects in the gene result in breast and ovarian cancer is still in a state of flux. It appears to be involved in multiple processes in the nucleus, such as repair and recombination, as well as transcriptional regulation (for review [4]). Recently, BRCA1 was reported to have the ability to bind directly to DNA, particularly branched structures [5], and regulates the key G2/M checkpoint protein Chk1 [6]. BRCA1 has also been shown to induce large-scale chromatin unfolding [7], which may play a role in both transcription and repair. While the specific roles of BRCA1 continue to be clarified, it is clear that functional BRCA1 protein is required to prevent breast transformation. Selective inactivation of BRCA1 in the breast results in blunted ductal development, breast hyperplasia and tumour formation [8].
Soon after its isolation, it became apparent that somatic mutations in the BRCA1 gene do not play a major role in sporadic breast tumour development. Specifically, no coding region mutations have been found [9] and noncoding regulatory region mutations are extremely rare $[10,11]$. Because sporadic tumours account for more than $90 \%$ of the total breast cancer burden, these findings were initially a major disappointment. However, a key study suggested that BRCA1 expression levels are reduced in sporadic tumours [12]. RNase A protection assays were used to examine mRNA levels in 19 sporadic tumour samples, and a consistent decrease in BRCA1 mRNA levels was observed in invasive tumours as compared with either paired normal tissue or ductal carcinoma in situ. The significance of this finding was enhanced when it was shown that decreasing BRCA1 levels increased the growth of tumour cells and that expression of BRCA1 led to growth arrest and apoptosis. Since then a number of other studies have confirmed this correlation and extended the observation.

One of the largest studies used 142 sporadic tumour samples and found a general correlation between grade 
and decreased BRCA1 expression, with $20 \%$ of tumours showing complete loss of BRCA1 protein [13]. Highgrade tumours generally have the lowest levels of BRCA1 [14] and exhibit higher proliferation rates [15]. Correlations between low BRCA1 levels, tumour grade, metastasis and prognostic markers such as oestrogen receptor status have also been made $[16,17]$. An inverse association with elevated c-erbB-2 levels has also been reported [18]. A recent study of 175 patients indicated an adverse effect on disease-free survival of low levels of BRCA1 [19]. Similar studies have correlated decreased BRCA1 levels with development of sporadic ovarian cancer [20]. This would be in accordance with the common function of BRCA1 as a tumour suppressor in both of these tissues. Overall, these findings suggest a model in which loss of BRCA1 activity, either by germ-line mutations or by downregulation of gene expression, leads to tumour formation in appropriate target tissues.

The data generated from the clinical studies cited above strongly suggest that decreased BRCA1 expression contributes to sporadic breast tumour progression. The functional importance of such a decrease has been confirmed by experimental manipulations of BRCA1 expression in cultured cells [12]. Regulation of protein stability may affect BRCA1 levels in certain circumstances [21], but this aspect of BRCA1 regulation is outside the scope of the present review. Therefore, here we address the most likely mechanisms for permanent decrease in BRCA1 expression in sporadic breast tumours. We then review the factors and signalling pathways that may be responsible for the modulation of BRCA1 expression in various developmental contexts. Finally, we discuss how disruption of these pathways could contribute to development of sporadic breast cancer, and whether transcription factors that regulate BRCA1 are candidate sporadic breast cancer genes.

\section{Loss of heterozygosity and methylation of the BRCA1 promoter}

There are several potential mechanisms that could lead to a permanent decrease in BRCA1 levels in sporadic breast tumours. One such mechanism is allelic loss of heterozygosity (LOH), in the absence of mutations (Fig. 1a), which has been observed at the BRCA1 locus in conjunction with a decrease in the steady-state levels of BRCA1 protein $[22,23]$. Normally, LOH alone would not contribute to a decrease in gene expression because the net result is two identical but genetically normal alleles. If one allele was subject to inactivation by methylation (see below), then $\mathrm{LOH}$ would lead to the presence of two methylated alleles and loss of expression. The observation of allelespecific expression of BRCA1 (Fig. 1b), in which examination of BRCA1 mRNA indicated that only one of the two genes was being expressed [24], could represent preliminary methylation of one allele. Currently, however, no studies have clearly demonstrated a functional link between $\mathrm{LOH}$ and promoter methylation.

Methylation, which can be permanent and heritable, is associated with decreased tumour suppressor gene expression in a number of disease contexts [25]. Examination of methylation patterns in the BRCA1 promoter region indicated that preferential methylation of some sites occurs (Fig. 1C), apparently only in tumours [26-30]. Moreover, promoter methylation may result in very low levels of BRCA1 [31]. Methylation is associated with greater chromatin compaction and lack of accessibility [32]. As with other systems, there is a question of whether methylation itself causes the initial decrease in BRCA1 expression or whether an initial transient decrease in transcriptional activity could have been the impetus for establishment of permanent methylation. Methylation appears to be a significant factor in BRCA1 regulation only in a small proportion of sporadic breast tumours [33]. Therefore, it is necessary to postulate that promoter silencing occurs by some other means in the majority of cases.

\section{The BRCA1 promoter}

The structure of the human BRCA1 locus is complicated (Fig. 2) in that it includes a partial duplication that results in a pseudo-BRCA1 gene and two distinct genes (i.e. NBR1 and NBR2) [34,35] which are divergently transcribed from both the pseudo-gene and BRCA1. This structure is not found in the mouse [36], which may be partly responsible for the differences between human and mouse breast cancer models (i.e. heterozygous brca1 knockout mice do not develop breast cancer, whereas human carriers do). The BRCA1 and NBR2 genes are separated by little more than 200 base pairs, and their transcription is divergent (Fig. 3). This region serves as the primary proximal promoter for the major breast-specific transcription start site located in exon 1a of BRCA1 [37]. Several initial studies of the BRCA1 promoter have been reported that have identified a possible upstream repressor element [38] and a positive element that is located some 200 base pairs upstream of this start site [39]. This region was able to direct expression in either the $B R C A 1$ or NBR2 direction, suggesting that it functions as a bidirectional transcriptional element [40]. There is some evidence to suggest that the $N B R 2$ and $B R C A 1$ genes may actually be reciprocally regulated. In a number of cell lines, higher levels of NBR2 expression are correlated with low BRCA1 levels [41]. This may reflect competition between the promoters for RNA polymerase II; it also suggests that activation of the NBR2 promoter could lead to decreased BRCA1 expression (Fig. 1d).

In culture BRCA1 expression increases in replicating cells [42], and stimulation of BRCA1 expression by oestrogen $[43,44]$ appears to result from the effect of this hormone on breast cell growth [45]. This proliferation-mediated 


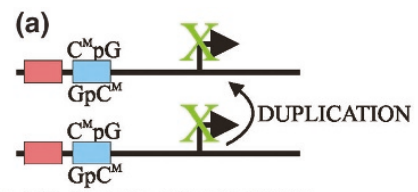

LOSS OF HETEROZYGOSITY

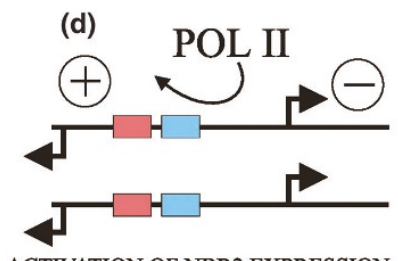

(g)

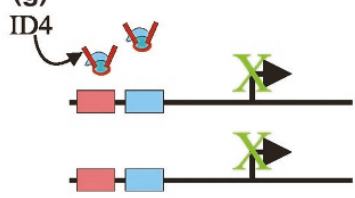

INHIBITION BY ID4 (b)

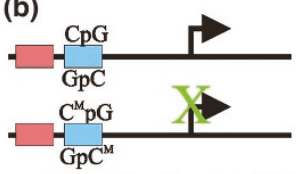

ALLELE SPECIFIC EXPRESSION

(e)

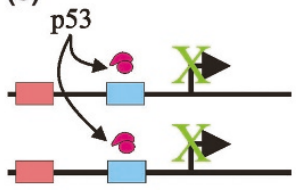

p53 MEDIATED REPRESSION

(h)

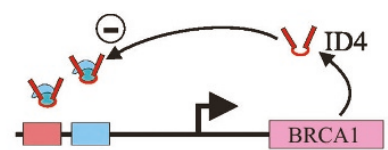

REGULATORY LOOP

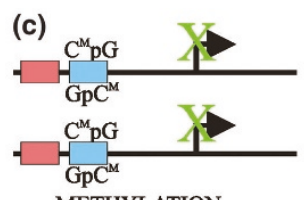

METHYLATION

(f)

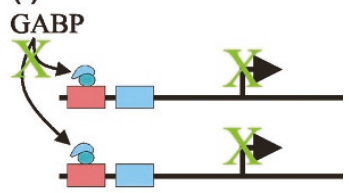

LOSS OF GABP ACTIVITY

Potential mechanisms for the reducing BRCA1 expression. Schematics of the two BRCA1 alleles are shown. (a) Endo-reduplication of a methylated allele would lead to complete loss of expression. (b) Expression from only one allele could be indicative of methylation of one of the promoters. (c) Methylation of both promoters through an unidentified mechanism would lead to a dramatic decrease in expression. (d) Increased NBR2 expression could lead to decreased BRCA1 expression. (e) p53 could inhibit factors such as E2F. (f) Loss of DNA binding by the GABP- $\alpha / \beta$ complex leads to decreased expression. (g) ID4 expression leads to the down regulation of the BRCA1 promoter, presumably through interaction with a transcription factor that normally regulates the promoter. (h) BRCA1 and ID4 levels appear to be coregulated.

\section{HUMAN BRCA1 LOCUS}
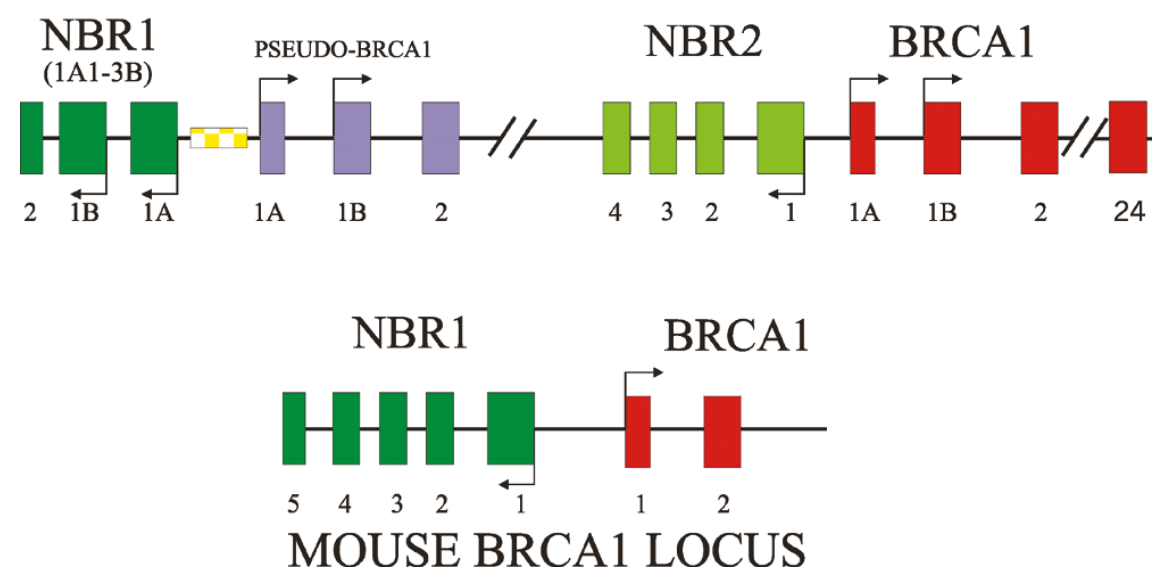

The structure of the human and mouse BRCA1 loci are shown. Transcription initiation sites are indicated by arrows. The general exon structure is indicated by the variously shaded boxes. The patterned box indicates the location of an acidic ribosomal phosphoprotein P1 pseudocopy [34], which appears to have been inserted into the region between NBR1 and the BRCA1 pseudo-gene. The BRCA1 gene appears to have two alternative first exons, although the $1 \mathrm{~A}$ exon appears to be used much more frequently. 
Figure 3

-264 ATAAGCCGCA ACTGGAAGAG TAGAGGCTAG AGGGCAGGCA CTTTATGGCA AACTCAGGTA

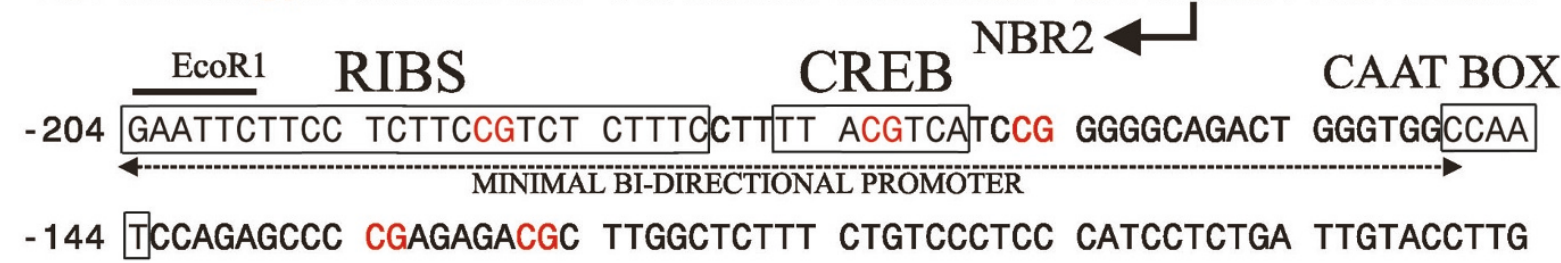

-84 ATtTCGTATT CTGAGAgGCT GCTGCTTAGC GGTAGCCCCT TGGTTTCCGT GGCAACGGAA
E2F

Sac I

The sequence of the promoter region between the NBR2 and the BRCA1 genes is indicated. The transcriptional start sites are indicated by the left and right pointing arrows for the respective genes. Binding sites for transcription factors identified as being important for promoter activity are boxed. The minimal bidirectional promoter [40] is indicated by the dashed line. The first exon of the BRCA1 gene is indicated by the shaded box. CpG dinucleotides that are potentially methylated are shown in red. The location of an EcoRI and Sac I are indicated by thick lines.

increase may act through an E2F site that has been characterized in the proximal promoter (Fig. 3) [46]. Conversely, p53 may inhibit BRCA1 expression by preventing E2F binding to this site (Fig. 1e) [47]. A negative regulatory site within the first intron has also been characterized, but the associated proteins have not been identified [48]. Studies of the methylation pattern of the promoter suggested that a potential cAMP-responsive element binding (CREB) protein site might be important for promoter function (Fig. 3) [26]. It was subsequently shown that this CREB site is a strong positive transcriptional element [49], although the site does not confer cAMP responsiveness on the promoter, as might be expected [50].

One transcription factor binding site has been identified that is critical for BRCA1 expression, but in a cell-line-specific manner. This RIBS element (Fig. 3) has been shown to bind the multisubunit ets protein GA-binding protein $(\mathrm{GABP})-\alpha / \beta$ and acts as an activator in MCF- 7 cells but not in T47-D cells [51]. This site is within the positive element previously described [39] and is included within the minimal bidirectional promoter element (Fig. 3) [40]. GABP- $\alpha$ and GABP- $\beta$ subunits have been shown to be present in both cell lines, but its DNA-binding activity was reduced in T47-D cells [51]. It is possible that mutation in one of the GABP subunits itself, or disruption of an upstream regulator, is responsible for loss of GABPdependent positive transcriptional activity in these cells (Fig. 1f). An elegant selection screening system using a library of riboyzmes was also able to identify a potential regulator of BRCA1 expression [52]. Inactivation of the helix-loop-helix $(\mathrm{HLH})$ protein inhibitor of differentiation 4 (ID4) was able to increase expression of BRCA1 in MCF- ship between the levels of ID4 and BRCA1, and ID4 expression may be regulated by oestrogen or by oestrogen's ability to induce growth. An interesting correlation between ID4 and BRCA1 expression has also come from efforts to identify transcriptionally regulated targets of BRCA1. Microarray analysis revealed that ID4 mRNA levels were increased upon BRCA1 induction [53]. Furthermore, there was a general positive correlation between BRCA1 and ID4 levels in a variety of breast and ovarian tumours [53]. This is in contrast to the inverse relationship found by artificial manipulation of ID4 levels [51]. This suggests that ID4 may be involved in a developmental regulatory loop that is disrupted during sporadic tumourigenesis (Fig. 1h).

\section{Developmental regulation of BRCA1 expression in mammary gland}

The developmental regulation of BRCA1 expression has been most extensively studied in the mouse [54-58]. During early embryogenesis BRCA1 (denoted brca1 in the mouse) is expressed diffusely in all three germ layers. Later, during foetal development, brca1 expression is highest in condensed tissues undergoing considerable proliferative, differentiative and morphogenic changes. These include the following: spinal ganglia and the neuroepithelium of the eye (neuroectoderm derived); somites and cartilage (mesoderm derived); liver and lung (endoderm derived); lense of the eye; and basal proliferative layers of the epidermis (ectodermally derived). Although expression of brca1 in the embryonic mammary gland has not been described, it is reasonable to suggest that its expression might parallel that seen in the epidermis because the glandular rudiment first forms as an invagination of this tissue. 


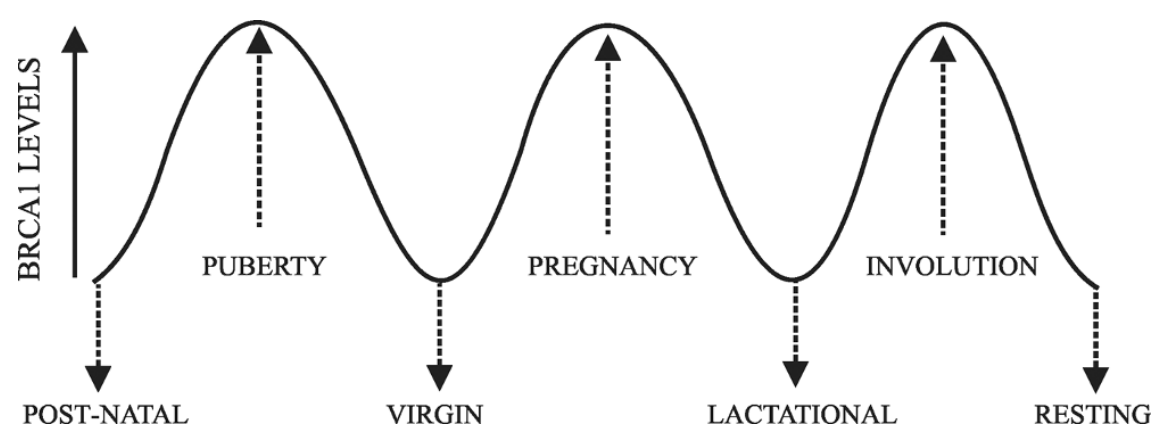

Brca1 expression in the mouse mammary gland. The line represents relative brca1 expression levels and is regulated in periodic waves during mammary gland development. Levels are low in the quiescent periods before puberty, in the virgin adult gland and in the resting gland. Levels are also low during lactational terminal differentiation. Levels are high during the proliferative periods at puberty and during pregnancy. Levels are also high during the apoptotic period of involution after weaning.

At birth the mouse mammary gland consists of a small number of epithelial ducts that radiate from the nipple a short distance into the underlying stromal fat pad. Before puberty the mammary ducts elongate into the fat pad at a rate that is similar to the overall growth of the animal. Further development of the gland takes place at puberty and during adult cycles of pregnancy, lactation and involution [59]. At puberty the ends of the ducts swell to form the proliferative terminal end-buds, which strongly express brca1 and initiate rapid ductal branching and elongation to the margins of the fat pad. After puberty, brca1 levels fall in the quiescent adult virgin gland. With the onset of pregnancy the terminal end-buds proliferate, branch and expand to form epithelial alveolar sacs. Throughout pregnancy brca1 is expressed at high levels in these developing alveoli. Later, during lactation, brca1 levels fall gradually as alveolar cells cease proliferating, terminally differentiate and produce milk. After weaning, milk production ceases, brca1 levels rise, and within a few days a massive apoptotic event is triggered. This drives involution and returns the gland to its quiescent state, whereupon brca1 levels once again fall. Therefore, in the postnatal mammary gland epithelial brca1 expression is induced in periodic waves that correspond to defined developmental periods in which intense proliferation, morphogenesis and/or apoptosis take place (Fig. 4). Given these observations, it is not unreasonable to expect that the molecular regulators of these developmental changes might also regulate brca1 expression.

\section{Molecular regulators of mammary development}

Mammary development is directed by at least three classes of molecular regulators. The first class consists of the systemic hormones, which are produced at distant sites but act within the mammary gland to initiate developmental change. Three such hormones, namely oestrogen
$[43,44]$, progesterone [60] and prolactin [61], have all been shown to upregulate BRCA1 expression. In culture, this upregulation is manifested under conditions that are conducive to nondifferentiative cellular proliferation [45]. In vivo, this would occur during pregnancy, when all three hormones contribute to the massive proliferative burst before alveolar morphogenesis and differentiation [62]. Interestingly, when prolactin later acts as a lactogenic, differentiative agent, it no longer upregulates BRCA1 expression [56].

The second class of regulators consists of soluble microenvironmental factors. These molecules are produced within the mammary tissues proper and they act over very short distances, often in a paracrine manner, to mediate functional interactions between the stromal and epithelial compartments of the gland [63]. Two such factors are hepatocyte growth factor and neuregulin, which mediate ductal branching and alveolar morphogenesis, respectively [64]. The ability of these agents to regulate BRCA1 expression in an appropriate developmental context in culture has not yet been determined. However, neuregulin, which signals through the erbB tyrosine kinase receptors, is active in vivo at the transition to nonproliferative, terminal differentiation when BRCA1 levels fall dramatically. Interestingly, one of the known regulators of the BRCA1 promoter, namely GABP- $\alpha / \beta$ [51], is a downstream mediator of neuregulin signalling in nerve cells [65].

The third class of mammary-specific regulators are extracellular matrix (ECM) proteins. For example, laminin, a glycoprotein that is located in the specialized basement membrane ECM, binds to cell surface integrin receptors and generates signals within the mammary epithelium that are required for lactational differentiation [66,67]. Furthermore, a metalloproteinase-mediated destruction of laminin triggers alveolar cell apoptosis during involution $[68,69]$. 
Therefore, an intact laminin-containing basement membrane may be a negative regulator of BRCA1 expression in differentiated mammary epithelial cells, and that this negative regulation could be released during involution [70].

\section{Conclusion}

BRCA1 expression is clearly modulated by developmental regulators in the normal mammary gland. At the same time, decreased BRCA1 expression is an early event in the process of breast transformation, and progresses with the degree of malignancy. Given the known molecular functions of BRCA1, it is reasonable to assume that such decreases lead to a relaxation in genome surveillance. This relaxation would not be deleterious during normal development because BRCA1 levels are lowest when mammary epithelial cells are either quiescent or terminally differentiated. However, changes in BRCA1 levels may also play an active role in regulating developmental processes, such as inducing postlactational regression. A number of transcription factors have been identified that regulate BRCA1 expression. Positive regulators such as E2F and GABP$\alpha / \beta$, as well as repressors such as ID4, combine to produce the varied developmental expression that is observed in vivo. These factors presumably lie at the end of a variety of signalling pathways that are initiated by molecular regulators of developmental change in the mammary gland. Importantly, many of the signals initiated by these regulators have themselves been implicated in mammary oncogenesis. Thus, we propose that mutations in the transcription factors themselves or alterations to the developmentally regulated signalling pathways that modulate their activity contribute to the inappropriate repression of BRCA1 expression. Obviously, these two possibilities are not mutually exclusive and could be overlapping.

One key regulator of terminal differentiation and BRCA1 repression is the basement membrane ECM. Cross-talk occurs between basement membrane-mediated signalling, prolactin signalling and morphogenic erbB receptor signalling during development $[67,66,71,72]$. This would ensure that in quiescent cells the ECM signal prevents BRCA1 induction, but during growth this blockade is lifted, and prolactin and erbB signals, which are proliferative outside the context of morphogenesis and lactational differentiation, result in BRCA1 induction. Tumour cell survival presumably requires abrogation of this BRCA1 induction. There are observational and experimental data that indirectly support this tentative hypothesis. First, in sporadic tumours BRCA1 levels are most affected after progression from ductal carcinoma in situ [12], a time when the basement membrane is undergoing chronic remodelling. Second, mammary-specific expression of an activated metalloprotease that remodels the basement membrane $[73,74]$ causes a morphogenic and stochastic tumour formation in transgenic mice that is reminiscent of the phenotype observed in the targeted BRCA1 knockout
[8]. Third, a developmentally inappropriate integrin signal switching that contributes to breast tumour progression causes erbB signalling to become oncogenic $[75,76]$. Fourth, oncogenic erbB signalling and BRCA1 expression are inversely correlated in tumour cells [18]. Finally, forced expression of ID1, which is closely related to the BRCA1 repressor ID4, causes mammary epithelial cells to proliferate rather than differentiate when they are exposed to a basement membrane ECM $[77,78]$.

Transcription factors that regulate the BRCA1 promoter directly modulate the production of this tumour suppressor, and thus their loss or gain of function will have the same functional consequences as inactivation of BRCA1 itself. This raises the question of whether these factors act as sporadic breast cancer genes. Optimal BRCA1 expression requires the concerted action of a number of transcription factors, so that inactivation of any one protein will affect BRCA1 levels. Given a random distribution of sporadic mutations in the genome, it may be more likely that one of a number of different transcription factor genes would be a target, rather than the BRCA1 gene itself. In addition, loss of activity from a single allele of a transcription factor gene may be sufficient to decrease BRCA1 expression significantly, with functional consequences. This may explain why sporadic mutations in BRCA1 have not been observed, because these may be rarer events than transcription factor gene mutations. Furthermore, as discussed above, loss of transcriptional regulators of BRCA1 may not require actual mutational events. Disruption of the signalling pathways that regulate BRCA1 expression could have long-term consequences for the associated transcriptional regulators, which persist through subsequent progression events. In some cases, BRCA1 transcription is reduced sufficiently for methylation of the promoter to occur, creating a self-sustaining repressed state. It may be possible to restore BRCA1 expression in tumours. This could be achieved by the use of demethylating agents such as deazacytadine, inducing alternative pathways where mutations have blocked other factors, or restoring developmental signals that have been co-opted. Induction of BRCA1 expression has been shown to induce apoptosis or reduce growth in tumour cells [12], and offers an alternative therapeutic approach that may be tumour specific.

\section{Acknowledgements}

CRM would like to acknowledge the support of the US Army Breast Cancer Program through grant DAMD17-01-1-0381. CDR would like to acknowledge the support of the Canadian Breast Cancer Research Initiative and the Canadian Institutes of Health Research.

\section{References}

1. Casey G: The BRCA1 and BRCA2 breast cancer genes. Curr Opin Oncol 1997, 9:88-93.

2. Miki Y, Swensen J, Shattuck-Eidens D, Futreal PA, Harshman K, Tavtigian S, Liu Q, Cochran C, Bennett LM, Ding W, et al.: A strong candidate for the breast and ovarian cancer susceptibility gene BRCA1. Science 1994, 266:66-71. 
3. Tavtigian SV, Simard J, Rommens J, Couch F, Shattuck-Eidens D, Neuhausen S, Merajver S, Thorlacius S, Offit K, Stoppa-Lyonnet D, Belanger C, Bell R, Berry S, Bogden R, Chen Q, Davis T, Dumont M, Frye C, Hattier T, Jammulapati S, Janecki T, Jiang P, Kehrer R, Leblanc JF, Goldgar DE, et al.: The complete BRCA2 gene and mutations in chromosome 13q-linked kindreds. Nature Genet 1996, 12:333-337.

4. Venkitaraman AR: Cancer susceptibility and the functions of BRCA1 and BRCA2. Cell 2002, 108:171-182.

5. Paull TT, Cortez D, Bowers B, Elledge SJ, Gellert M: Direct DNA binding by Brca1. Proc Natl Acad Sci USA 2001, 98:60866091.

6. Yarden RI, Pardo-Reoyo S, Sgagias M, Cowan KH, Brody LC: BRCA1 regulates the G2/M checkpoint by activating Chk1 kinase upon DNA damage. Nat Genet 2002, 30:285-289.

7. Ye Q, Hu YF, Zhong H, Nye AC, Belmont AS, Li R: BRCA1induced large-scale chromatin unfolding and allele-specific effects of cancer-predisposing mutations. J Cell Biol 2001, 155:911-921.

8. Xu X, Wagner KU, Larson D, Weaver Z, Li C, Ried T, Hennighausen L, Wynshaw-Boris A, Deng CX: Conditional mutation of Brca1 in mammary epithelial cells results in blunted ductal morphogenesis and tumour formation. Nat Genet 1999, 22: 37-43.

9. Futreal PA, Liu Q, Shattuck-Eidens D, Cochran C, Harshman K, Tavtigian S, Bennett LM, Haugen-Strano A, Swensen J, Miki Y, et al.: BRCA1 mutations in primary breast and ovarian carcinomas. Science 1994, 266:120-122.

10. Papa S, Seripa D, Merla G, Gravina C, Giai M, Sismondi P, Rinaldi M, Serra A, Saglio G, Fazio VM: Identification of a possible somatic BRCA1 mutation affecting translation efficiency in an early-onset sporadic breast cancer patient. J Natl Cancer Inst 1998, 90:1011-1012.

11. van der LM, Cleton-Jansen AM, van Eijk R, Morreau $H$, van Vliet $M$, Kuipers-Dijkshoorn N, Olah E, Cornelisse CJ, Devilee P: A sporadic breast tumor with a somatically acquired complex genomic rearrangement in BRCA1. Genes Chromosomes Cancer 2000, 27:295-302.

12. Thompson ME, Jensen RA, Obermiller PS, Page DL, Holt JT: Decreased expression of BRCA1 accelerates growth and is often present during sporadic breast cancer progression. Nat Genet 1995, 9:444-450.

13. Taylor J, Lymboura M, Pace PE, A'hern RP, Desai AJ, Shousha S, Coombes RC, Ali S: An important role for BRCA1 in breast cancer progression is indicated by its loss in a large proportion of non-familial breast cancers. Int J Cancer 1998, 79:334342.

14. Wilson CA, Ramos L, Villasenor MR, Anders KH, Press MF, Clarke K, Karlan B, Chen JJ, Scully R, Livingston D, Zuch RH, Kanter $\mathrm{MH}$, Cohen S, Calzone FJ, Slamon DJ: Localization of human BRCA1 and its loss in high-grade, non-inherited breast carcinomas. Nat Genet 1999, 21:236-240.

15. Jarvis EM, Kirk JA, Clarke CL: Loss of nuclear BRCA1 expression in breast cancers is associated with a highly proliferative tumor phenotype. Cancer Genet Cytogenet 1998, 101:109115.

16. Lee WY, Jin YT, Chang TW, Lin PW, Su IJ: Immunolocalization of BRCA1 protein in normal breast tissue and sporadic invasive ductal carcinomas: a correlation with other biological parameters. Histopathology 1999, 34:106-112.

17. Seery LT, Knowlden JM, Gee JM, Robertson JF, Kenny FS, Ellis IO, Nicholson RI: BRCA1 expression levels predict distant metastasis of sporadic breast cancers. Int J Cancer 1999, 84: 258-262.

18. Yoshikawa K, Honda K, Inamoto T, Shinohara H, Yamauchi A, Suga K, Okuyama T, Shimada T, Kodoma H, Noguchi S, Gazdar AF, Yamaoka Y, Takahashi R: Reduction of BRCA1 protein expression in Japenese sporadic breast carcinomas and its frequent loss in BRCA1-associated cases. Clin Cancer Res 1999, 5:1249-1261.

19. Yang Q, Sakurai T, Mori I, Yoshimura G, Nakamura M, Nakamura Y, Suzuma T, Tamaki T, Umemura T, Kakudo K: Prognostic significance of BRCA1 expression in Japanese sporadic breast carcinomas. Cancer 2001, 92:54-60.

20. Russell PA, Pharoah PD, De Foy K, Ramus SJ, Symmonds I, Wilson A, Scott I, Ponder BA, Gayther SA: Frequent loss of BRCA1 mRNA and protein expression in sporadic ovarian cancers. Int J Cancer 2000, 87:317-321.

21. Blagosklonny MV, An WG, Melillo G, Nguyen P, Trepel JB, Neckers LM: Regulation of BRCA1 by protein degradation. Oncogene 1999, 18:6460-6468.

22. Rio PG, Pernin D, Bay JO, Albuisson E, Kwiatkowski F, De Latour $M$, Bernard-Gallon DJ, Bignon YJ: Loss of heterozygosity of BRCA1, BRCA2 and ATM genes in sporadic invasive ductal breast carcinoma. Int J Oncol 1998, 13:849-853.

23. Rio PG, Maurizis JC, Peffault DL, Bignon YJ, Bernard-Gallon DJ: Quantification of BRCA1 protein in sporadic breast carcinoma with or without loss of heterozygosity of the BRCA1 gene. Int $J$ Cancer 1999, 80:823-826.

24. Ozcelik H, To MD, Couture J, Bull SB, Andrulis IL: Preferential allelic expression can lead to reduced expression of BRCA1 in sporadic breast cancers. Int J Cancer 1998, 77:1-6.

25. Herman JG, Baylin SB: Promoter-region hypermethylation and gene silencing in human cancer. Curr Top Microbiol Immunol 2000, 249:35-54.

26. Mancini DN, Rodenhiser DI, Ainsworth PJ, O'Malley FP, Singh SM, Xing W, Archer TK: CpG methylation within the 5' regulatory region of the BRCA1 gene is tumor specific and includes a putative CREB binding site. Oncogene 1998, 16:1161-1169.

27. Magdinier F, Ribieras S, Lenoir GM, Frappart L, Dante R: Downregulation of BRCA1 in human sporadic breast cancer; analysis of DNA methylation patterns of the putative promoter region. Oncogene 1998, 17:3169-3176.

28. Dobrovic A, Simpfendorfer D: Methylation of the BRCA1 gene in sporadic breast cancer. Cancer Res 1997, 57:3347-3350.

29. Rice JC, Massey-Brown KS, Futscher BW: Aberrant methylation of the BRCA1 CpG island promoter is associated with decreased BRCA1 mRNA in sporadic breast cancer cells. Oncogene 1998, 17:1807-1812.

30. Magdinier F, Billard LM, Wittmann G, Frappart L, Benchaib M, Lenoir GM, Guerin JF, Dante R: Regional methylation of the 5 end $\mathrm{CpG}$ island of BRCA1 is associated with reduced gene expression in human somatic cells. FASEB J 2000, 14:15851594

31. Rice JC, Ozcelik H, Maxeiner P, Andrulis I, Futscher BW: Methylation of the BRCA1 promoter is associated with decreased BRCA1 mRNA levels in clinical breast cancer specimens. Carcinogenesis 2000, 21:1761-1765.

32. Rice JC, Futscher BW: Transcriptional repression of BRCA1 by aberrant cytosine methylation, histone hypoacetylation and chromatin condensation of the BRCA1 promoter. Nucleic Acids Res 2000, 28:3233-3239.

33. Catteau A, Harris WH, Xu CF, Solomon E: Methylation of the BRCA1 promoter region in sporadic breast and ovarian cancer: correlation with disease characteristics. Oncogene 1999, 18:1957-1965

34. Brown MA, Xu CF, Nicolai $H$, Griffiths $B$, Chambers JA, Black D, Solomon E: The 5' end of the BRCA1 gene lies within a duplicated region of human chromosome 17q21. Oncogene 1996, 12:2507-2513.

35. Xu CF, Brown MA, Nicolai H, Chambers JA, Griffiths BL, Solomon $\mathrm{E}$ : Isolation and characterisation of the NBR2 gene which lies head to head with the human BRCA1 gene. Hum Mol Genet 1997, 6:1057-1062.

36. Chambers JA, Solomon E: Isolation of the murine Nbr1 gene adjacent to the murine Brca1 gene. Genomics 1996, 38:305 313.

37. Xu CF, Brown MA, Chambers JA, Griffiths B, Nicolai H, Solomon E: Distinct transcription start sites generate two forms of BRCA1 mRNA. Hum Mol Genet 1995, 4:2259-2264.

38. Xu C-F, Chambers JA, Solomon E: Complex regulation of the BRCA1 gene. J Biol Chem 1997, 272:20994-20997.

39. Thakur S, Croce CM: Positive regulation of the BRCA1 promoter. J Biol Chem 1999, 274:8837-8843.

40. Suen TC, Goss PE: Transcription of BRCA1 is dependent on the formation of a specific protein-DNA complex on the minimal BRCA1 Bi-directional promoter. J Biol Chem 1999, 274:31297-31304.

41. Dimitrov SD, Matouskova E, Forejt J: Expression of BRCA1, NBR1 and NBR2 genes in human breast cancer cells. Folia Biol (Praha) 2001, 47:120-127.

42. Gudas JM, Li T, Nguyen $\mathrm{H}$, Jensen $\mathrm{D}$, Rauscher FJ, Cowan $\mathrm{KH}$ : Cell cycle regulation of BRCA1 messenger RNA in human breast epithelial cells. Cell Growth Differ 1996, 7:717-723. 
43. Spillman MA, Bowcock AM: BRCA1 and BRCA2 mRNA levels are coordinately elevated in human breast cancer cells in response to estrogen. Oncogene 1996, 13:1639-1645.

44. Romagnolo D, Annab LA, Thompson TE, Risinger JI, Terry LA, Barrett JC, Afshari CA: Estrogen upregulation of BRCA1 expression with no effect on localization. Mol Carcinog 1998, 22:102-109.

45. Marks JR, Huper G, Vaughn JP, Davis PL, Norris J, McDonnell DP, Wiseman RW, Futreal PA, Iglehart JD: BRCA1 expression is not directly responsive to estrogen. Oncogene 1997, 14:115-121.

46. Wang A, Schneider-Broussard R, Kumar AP, MacLeod MC Johnson DG: Regulation of BRCA1 expression by the Rb-E2F pathway. J Biol Chem 2000, 275:4532-4536.

47. MacLachlan TK, Dash B, Dicker DT, El-Deiry W: Repression of BRCA1 through a feedback loop involving p53. J Biol Chem 2000, 275:2777-2785.

48. Suen TC, Goss PE: Identification of a novel transcriptional repressor element located in the first intron of the human BRCA1 gene. Oncogene 2001, 20:440-450.

49. DiNardo DN, Butcher DT, Robinson DP, Archer TK, Rodenhiser DI: Functional analysis of CpG methylation in the BRCA1 promoter region. Oncogene 2001, 20:5331-5340.

50. Atlas E, Stramwasser M, Mueller CR: A CREB site in the BRCA1 proximal promoter acts as a constitutive transcriptional element. Oncogene 2001, 20:7110-7114.

51. Atlas E, Stramwasser M, Whiskin K, Mueller CR: GA-binding protein alpha/beta is a critical regulator of the BRCA1 promoter. Oncogene 2000, 19:1933-1940.

52. Beger C, Pierce LN, Kruger M, Marcusson EG, Robbins JM, Welcsh P, Welch PJ, Welte K, King MC, Barber JR, Wong-Staal F: Identification of Id4 as a regulator of BRCA1 expression by using a ribozyme-library-based inverse genomics approach. Proc Natl Acad Sci USA 2001, 98:130-135.

53. Welcsh PL, Lee MK, Gonzalez-Hernandez RM, Black DJ, Mahadevappa M, Swisher EM, Warrington JA, King MC: BRCA1 transcriptionally regulates genes involved in breast tumorigenesis. Proc Natl Acad Sci USA 2002, 99:7560-7565.

54. Marquis ST, Rajan JV, Wynshaw-Boris A, Xu J, Yin GY, Abel KJ, Weber BL, Chodosh LA: The developmental pattern of Brca1 expression implies a role in differentiation of the breast and other tissues. Nat Genet 1995, 11:17-26.

55. Lane TF, Deng C, Elson A, Lyu MS, Kozak CA, Leder P: Expression of Brca1 is associated with terminal differentiation of ectodermally and mesodermally derived tissues in mice. Genes Dev 1995, 9:2712-2722.

56. Rajan JV, Wang M, Marquis ST, Chodosh LA: Brca2 is coordinately regulated with Brca1 during proliferation and differentiation in mammary epithelial cells. Proc Natl Acad Sci USA 1996, 93:13078-13083.

57. Blackshear PE, Goldsworthy SM, Foley JF, McAllister KA, Bennett LM, Collins NK, Bunch DO, Brown P, Wiseman RW, Davis BJ: Brca1 and Brca2 expression patterns in mitotic and meiotic cells of mice. Oncogene 1998, 16:61-68.

58. Rajan JV, Marquis ST, Gardner HP, Chodosh LA: Developmental expression of Brca2 colocalizes with Brca1 and is associated with proliferation and differentiation in multiple tissues. Dev Biol 1997, 184:385-401.

59. Hennighausen L, Robinson GW: Think globally, act locally: the making of a mouse mammary gland. Genes Dev 1998, 12: 449-455.

60. Gudas JM, Nguyen H, Li T, Cowan KH: Hormone-dependent regulation of BRCA1 in human breast cancer cells. Cancer Res 1995, 55:4561-4565.

61. Favy DA, Rio P, Maurizis JC, Hizel C, Bignon YJ, Bernard-Gallon DJ: Prolactin-dependent up-regulation of BRCA1 expression in human breast cancer cell lines. Biochem Biophys Res Commun 1999, 258:284-291.

62. Laud K, Hornez L, Gourdou I, Belair L, Arnold A, Peyrat JP, Djiane $\mathrm{J}$ : Expression of BRCA1 gene in ewe mammary epithelial cells during pregnancy: regulation by growth hormone and steroid hormones. Eur J Endocrinol 2001, 145:763-770.

63. Wiseman BS, Werb Z: Stromal effects on mammary gland development and breast cancer. Science 2002, 296:10461049.

64. Yang Y, Spitzer E, Meyer D, Sachs M, Niemann C, Hartmann G, Weidner KM, Birchmeier C, Birchmeier W: Sequential requirement of hepatocyte growth factor and neuregulin in the mor- phogenesis and differentiation of the mammary gland. J Cell Biol 1995, 131:215-226.

65. Fromm L, Burden SJ: Synapse-specific and neuregulin-induced transcription require an ets site that binds GABPalpha/GABPbeta. Genes Dev 1998, 12:3074-3083.

66. Streuli $\mathrm{CH}$, Schmidhauser C, Bailey N, Yurchenco P, Skubitz AP, Roskelley C, Bissell MJ: Laminin mediates tissue-specific gene expression in mammary epithelia. J Cell Biol 1995, 129:591603.

67. Streuli $\mathrm{CH}$, Edwards $\mathrm{GM}$, Delcommenne M, Whitelaw $\mathrm{CB}$, Burdon TG, Schindler C, Watson CJ: Stat5 as a target for regulation by extracellular matrix. J Biol Chem 1995, 270:2163921644.

68. Talhouk RS, Bissell MJ, Werb Z: Coordinated expression of extracellular matrix-degrading proteinases and their inhibitors regulates mammary epithelial function during involution. $J$ Cell Biol 1992, 118:1271-1282.

69. Fata JE, Leco KJ, Voura EB, Yu HY, Waterhouse P, Murphy G, Moorehead RA, Khokha R: Accelerated apoptosis in the Timp3-deficient mammary gland. J Clin Invest 2001, 108:831-841.

70. O'Connell FC, Martin F: Laminin-rich extracellular matrix association with mammary epithelial cells suppresses brca1 expression. Cell Death Differ 2000, 7:360-367.

71. Myers CA, Schmidhauser C, Mellentin-Michelotti J, Fragoso G, Roskelley CD, Casperson G, Mossi R, Pujuguet P, Hager G Bissell MJ: Characterization of BCE-1, a transcriptional enhancer regulated by prolactin and extracellular matrix and modulated by the state of histone acetylation. $\mathrm{Mol} \mathrm{Cell} \mathrm{Biol}$ 1998, 18:2184-2195.

72. Troyer KL, Lee DC: Regulation of mouse mammary gland development and tumorigenesis by the ERBB signaling network. J Mammary Gland Biol Neoplasia 2001, 6:7-21.

73. Sympson CJ, Talhouk RS, Alexander CM, Chin JR, Clift SM, Bissell MJ, Werb Z: Targeted expression of stromelysin-1 in mammary gland provides evidence for a role of proteinases in branching morphogenesis and the requirement for an intact basement membrane for tissue-specific gene expression. $J$ Cell Biol 1994, 125:681-693.

74. Sternlicht MD, Lochter A, Sympson CJ, Huey B, Rougier JP, Gray JW, Pinkel D, Bissell MJ, Werb Z: The stromal proteinase MMP3/stromelysin-1 promotes mammary carcinogenesis. Cell 1999, 98:137-146.

75. Weaver VM, Petersen OW, Wang F, Larabell CA, Briand $P$, Damsky C, Bissell MJ: Reversion of the malignant phenotype of human breast cells in three-dimensional culture and in vivo by integrin blocking antibodies. J Cell Biol 1997, 137:231-245.

76. Wang F, Weaver VM, Petersen OW, Larabell CA, Dedhar S, Briand P, Lupu R, Bissell MJ: Reciprocal interactions between beta1-integrin and epidermal growth factor receptor in threedimensional basement membrane breast cultures: a different perspective in epithelial biology. Proc Natl Acad Sci USA 1998, 95:14821-14826.

77. Desprez PY, Hara E, Bissell MJ, Campisi J: Suppression of mammary epithelial cell differentiation by the helix-loop-helix protein Id-1. Mol Cell Biol 1995, 15:3398-3404.

78. Parrinello S, Lin CQ, Murata K, Itahana $\mathrm{Y}$, Singh J, Krtolica A, Campisi J, Desprez PY: Id-1, ITF-2, and Id-2 comprise a network of helix-loop-helix proteins that regulate mammary epithelial cell proliferation, differentiation, and apoptosis. $J$ Biol Chem 2001, 276:39213-39219.

\section{Correspondence}

Christopher R Mueller, Cancer Research Laboratories, Rm 366 Botterell Hall, Queen's University, Kingston, Ontario, Canada K7L 3N6. Tel: +1 613533 6751; fax: +1 613533 6830; e-mail: muellerc@post.queensu.ca 